\title{
CROSS TALK ANTARA SEL PUNCA KANKER DENGAN LINGKUNGAN MIKRO
}

\author{
Ruby Riana Asparini \\ Fakultas Kedokteran Universitas Muhammadiyah Malang \\ j1. Bendungan Sutami No. 188a Malang \\ Email : rubyriana16@gmail.com
}

\begin{abstract}
ABSTRAK
Pengetahuan tentang biologi tumor dan terapi tumor telah berkembang. Namun tumor tetap merupakan penyakit umum yang mematikan di seluruh dunia. Sel punca kanker adalah bagian dari sel kanker dengan kemampuan sel punca, yang dapat mendorong pertumbuhan tumor, kekambuhan dan tahan terhadap banyak perawatan antikanker saat ini.Tumor padat dianggap sebagai "organ" yang terdiri dari sel kanker dan stroma tumor. Lingkungan mikro tumor membentuk stroma tumor, yang menempati sebagian besar massa tumor, termasuk matriks ekstraselular (ECM), sel induk mesenchymal (MSC), sel endotel, sel imun, dan, lebih dari itu, jaringan sitokin dan faktor pertumbuhan. Lingkungan mikro atau nichesekitarsel punca kanker sebagian besar mengatur nasib seluler mereka. Pengetahuan terbaru mengungkapkan bahwa lingkungan mikro mendukung pembaharuan diri sel punca kanker dan sekaligus berfungsi sebagai penghalang fisik terhadap pemberian obat. Lingkungan mikro tumor memainkan peran penting dalam setiap tahap perkembangan tumor.
\end{abstract}

Kata Kunci : Cross Talk, sell punca.

\section{ABSTRACT}

Knowledge of tumor biology and tumor therapy has grown. But tumors remain a deadly common disease worldwide. Cancer stem cells are part of cancer cells with stem cell capability, which can promote tumor growth, recurrence and resistance to many current anticancer treatments. Solid tumors are considered as "organs" comprising cancer cells and tumor stroma. The tumor microenvironment forms tumor stroma, which occupies most of the tumor mass, including the extracellular matrix (ECM), mesenchymal stem cells (MSC), endothelial cells, immune cells, and, moreover, cytokine tissue and growth factors. The microcosms or nichesekitarsel of cancer stem largely regulate their cellular fate. Recent knowledge reveals that the microenvironment supports the self-renewal of cancer stem cells and also serves as a physical barrier to drug delivery. The tumor microenvironment plays an important role in every stage of tumor development.

Keyword : cross talk, stem cells. 


\section{PENDAHULUAN}

Sel punca kanker didefinisikan sebagai subpopulasi sel dalam massa tumor yang memiliki kemampuan sebagai sel induk. Sel punca kanker dapat diturunkan dari sel punca dewasa atau sel progenitor, dan dari sel yang terdiferensiasi akhir yang mengalami perubahan epigenetik.Sel ganas memanfaatkan sinyal spesifik sel punca untuk mendorong perkembangan tumor (Garcia-Mazas et al., 2017).

Peran sel punca kanker pertama kali diketahui pada tahun 1994 dengan studi leukemia myeloid akut manusia.Penelitian tersebut melakukan transplantasi populasi sel inisiator AML dari pasien AML ke tikus, yang kemudian terjadi Severe Combined Immune Deficient (SCID).Sel inisiator leukemia berkembang berdasarkan ekspresi marker permukaan sel (CD34+/ CD38). Sel punca kanker manusia diidentifikasi pada tumor padat, termasuk payudara dan kanker otak pada tahun 2003. Laporan selanjutnya mengidentifikasi sel punca kanker dalam berbagai jenis tumor, termasuk kolon, pankreas, paru-paru, prostat, melanoma, dan glioblastoma. Paling sedikit 100 sel punca kanker mampu membentuk tumor pada tikus non-obesitas / SCID (Yua et al., 2012).

Tumor padat dianggap sebagai "organ" yang terdiri dari sel kanker dan lingkungan mikro tumor.Lingkungan mikro tumor mencakup extracellular matrix (ECM), sel induk mesenchymal (MSC), sel endotel, sel imun, dan, lebih jauh lagi, jaringan sitokin dan faktor pertumbuhan. Sel punca kanker juga membutuhkan lingkungan mikro khusus yang dikenal sebagai "niche sel punca kanker " untuk mengatur proliferasi dan menyelamatkan sel induk dari pengurangan (Xie \& Li, 2007).

Lingkungan mikro yang mengelilingi sel punca kanker memainkan banyak peran termasuk sebagai jangkar mekanis untuk sel induk dan cross talk yang dimediasi oleh faktor kontak langsung dan / atau faktor ekstraselular tidak langsung.Makalah ini bertujuan memahamkan cross talk antara sel punca kanker dan lingkungan mikro.

\section{Diskusi}

Prinsip dasar sistem evolusi Darwin adalah variasi genetik tanpa tujuan dari individu reproduktif, disertai seleksi alam varian terkuat.Kanker adalah contoh yang jelas dari sistem semacam itu. Sebagian besar proses mutasi memiliki bias pada tingkat urutan DNA. Spektrum mutasi tertentu dalam sel kanker dapat menjadi cerminan dari proses perbaikan rawan kesalahan (error prone) atau terkait dengan pemaparan genotoksik (misalnya, karsinogen rokok, sinar ultraviolet dan obat kemoterapi (Greaves \& Maley, 2012).

Heterogenitas sel tumor sekarang merupakan ciri kanker yang dapat diterima secara luas dan dapat didiskusikan pada tingkat genetik dan perkembangan, keduanya saling terkait erat. Pada tingkat genetik, sel tumor menyajikan variabilitas genetik intrinsik, yang menghasilkan beberapa subclone kanker yang berkembang mengikuti proses Darwin dalam usaha untuk beradaptasi terhadap lingkungan. Proses ini menyebabkan pengayaan sel menghadirkan mutasi yang menguntungkan dan fenotip yang lebih agresif (Greaves \& Maley, 2012). Pada tingkat perkembangan, telah dikonfirmasi bahwa inisiasi dan rekurensi tumor didorong oleh subpopulasi sel tumor terpilih yang memiliki ketahanan tinggi terhadap terapi konvensional dan yang memanfaatkan fitur spesifik sel punca.

Sel punca kanker secara struktural dan fungsional berbeda dari sel lain dalam massa tumor dan dianggap memainkan peran sentral dalam perkembangan tumor. Sel punca kanker ditandai dengan resistensi terhadap terapi antikanker dan merupakan akar metastasis tumor dan kekambuhan.Radiasi dan kemoterapi saat ini membunuh sebagian besar sel kanker namun seringkali tidak mampu menghilangkan sel punca kanker, yang dilindungi oleh mekanisme resistensi spesifik (Magee et al., 2012).

Sel punca kanker memiliki interaksi kompleks dengan komponen lingkungan mikro tumor.Sitokin memainkan peran penting dalam komunikasi interselular, dan banyak di antaranya mengatur fenotip sel punca dalam berbagai konteks termasuk tumor. Sel di lingkungan mikro tumor dapat menghasilkan faktor seperti ligan VEGF, TGF-â, matriks metalo- proteinase (MMPs), FGF, HGF, EGF, SDF-1, IGF, PDGF, Wnt, Notch ligand, dan Hedgehog, yang merangsang sel punca kanker memperbarui diri, menginduksi angiogenesis, dan merekrut tumor- associated macrophages (TAM), neutrofil, dan sel mast, yang mengeluarkan faktor pertumbuhan tambahan yang mendorong invasi sel tumor dan metastasis seperti tampak pada gambar 1. 


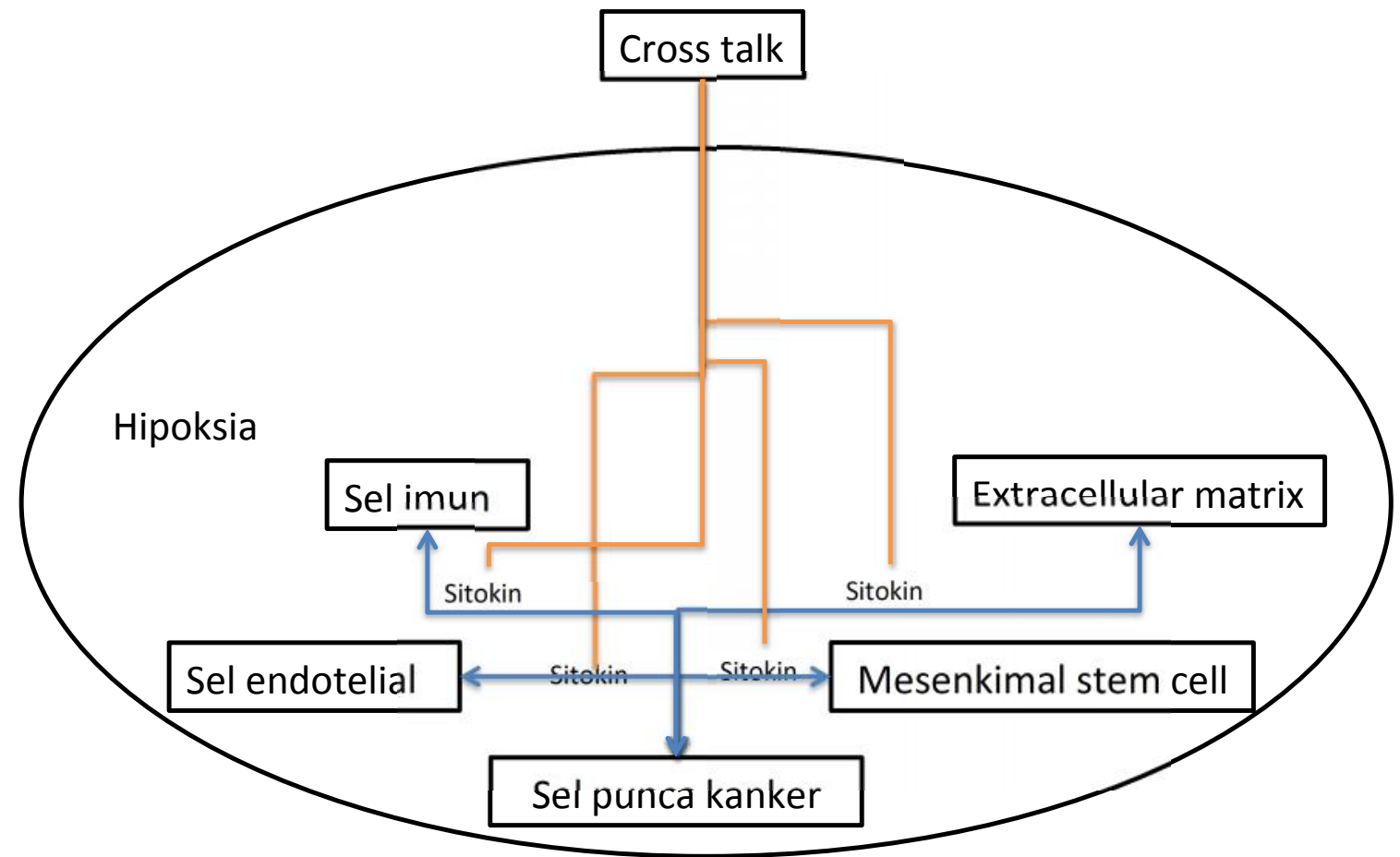

Gambar 1. Skematik interaksi antara sel punca kanker dan lingkungan mikro.Progresi tumor memerlukan interaksi dan kerjasama yang baik antara sel punca kanker dan "niche" atau lingkungan mikro.Umpan balik 2 arah antara molekul sel punca kanker dan ECM, sel stroma, dan, lebih dari itu, jaringan sitokin dan eksosom meningkatkan proliferasi dan kelangsungan hidup sel punca kanker dan juga memiliki efek langsung terhadap keganasan sel kanker.

Beberapa sel kanker memerlukan kerjasama dari sel stroma untuk membentuk tumor, menunjukkan bahwa sel punca kanker didukung oleh faktor lingkungan sekitarnya.Sel punca kanker dapat meningkatkan angiogenesis tumor, dan keberhasilan terapi signifikan dapat dicapai dengan pengobatan inhibitor angiogenesis.Diketahui bahwa sel punca kanker tidak hanya sekedar beradaptasi dengan niche yang ada tapi lebih agresif menghasilkan lingkungan seperti itu (Xie \& Li, 2007).

Banyak upaya telah dilakukan untuk menentukan bagaimana komponen seluler dari lingkungan mikro kanker memulai dan mempromosikan perkembangan kanker.Sel punca kanker dianggap membentuk lingkungan mikro mereka sendiri dengan merekrut dan mengaktifkan jenis sel tertentu.MSC adalah salah satu komponen penting yang mengeluarkan berbagai sitokin yang memiliki fungsi parakrin dan autokrin di lingkungan tumor.Mereka immunoprivileged, berperan penting dalam kanker, dan memberikan lingkungan mikro kanker yang menguntungkan untuk pemulihan sel punca kanker (Waterman et al., 2012).

Sel punca kanker payudara dapat menghasilkan interleukin-6 yang menarik dan mengaktifkan MSC untuk menghasilkan sitokin sel punca kanker yang mendukung CXCL7.MSCs mempromosikan pertumbuhan tumor dan mendukung angiogenesis di niche tumor ovarium.Selain itu, MSC telah terlibat dalam tumorigenesis melalui beberapa mekanisme, termasuk mempromosikan proliferasi dan metastasis sel kanker dan meningkatkan angiogenesis, di samping pembentukan lingkungan mikro yang imunosupresif (Lin et al., 2011).

Nichetumor mengacu pada lingkungan mikro yang berinteraksi dengan sel tumor dan mengatur nasib mereka.Niche tumor telah dinyatakan sebagai penghalang penting untuk pengobatan kanker dan melalui empat fitur yang berbeda: niche vaskular, niche inflamasi dan imunosupresif, niche hipoksia dan ECM.Semua terkait erat di antara mereka sendiri, dengan fenotipe sel punca kanker.Lingkungan mikro tumor di masa lalu dilihat sebagai keuntungan, karena meningkatkan permeabilitas dan retensi obat berukuran nano dalam tumor (yaitu efek enhanced 
permeability and retention/EPR) (Garcia-Mazas et al., 2017).

Namun, pembuluh darah tumor sangat tidak teratur dan bisa menyempit di beberapa tempat, sementara bocor di tempat lain. Pertumbuhan pembuluh darah tumor yang tidak teratur ini juga menghasilkan cabang non-fungsional, yang menyebabkan area yang tidak mudah diakses dengan kemoterapi (Jain, 2005). Selain itu, akumulasi stroma pada tumor dan tekanan intratumoral tinggi juga mencegah pengangkutan obat ke daerah dalam.Sebuah survei literatur baru-baru ini menunjukkan bahwa hanya $0,7 \%$ dari dosis pembawa nano yang masuk ke tumor padat, menunjukkan kegagalan keseluruhan konsep penargetan pasif seperti yang dipahami saat ini.

Selain efek penghalangnya terhadap pemberian obat, niche tumor juga memberi sinyal penting, seringkali dikaitkan dengan fenotipe sel induk kanker, yang mendorong penyebaran dan perlindungan tumor.Sel punca kanker dan niche mereka telah diakui sebagai fitur penting perkembangan kanker pada tahun-tahun terakhir, dan saat ini sedang dalam fokus program intens untuk pengembangan obat. Memang, beberapa prototip telah dikembangkan sampai pada tahap implementasi klinis atau sedang dalam uji klinis lanjutan.Sebagian besar program masih berfokus pada aspek sel punca kanker dan niche tumor yang terpisah, padahal saling terkait erat dan penanganannya menjadi tidak efektif (Garcia-Mazas et al., 2017).

Hipoksia adalah salah satu fenomena biologis mendasar yang terkait secara intrinsik dengan berbagai tumor padat dan dapat meningkatkan fenotipe sel punca kanker.Ini adalah kondisi penting dari lingkungan mikro tumor terjadi karena vaskularisasi kacau dan difusi oksigen yang buruk pada kanker yang solid.Banyak bukti menunjukkan bahwa sel punca kanker ada di lingkungan mikro hipoksia, yang mungkin bermanfaat untuk pemeliharaan sel-sel ini di hampir semua jaringan tubuh. Hipoksia adalah indikator yang baik untuk keluaran penyakit karena memilih sel kanker yang paling invasif dan meningkatkan resistensi terhadap terapi (Gaelzer et al., 2017).

Ringkasan dan implikasi klinis

Teori sel punca kanker sangat menarik bagi peneliti dan dokter, karena sel punca kanker sangat penting bagi biologi sel kanker dan terapi kanker. Perkembangan kanker bukan semata-mata merupakan proses intrinsik sel yang digerakkan oleh pengumpulan kesalahan epigenetik atau genetik pada sel yang berubah, namun juga bergantung pada lingkungan mikro mereka. Lingkungan mikro yang mengelilingi sel punca kankermemainkan banyak peran termasuk sebagai jangkar mekanis untuk sel induk dan komunikasi cross talk yang dimediasi oleh faktor kontak langsung dan atau faktor ekstraselular tidak langsung.Sel punca kankermelindungi niche mereka dan, sebaliknya, niche berkontribusi untuk meningkatkan ketahanan terapi sel punca kanker.

\section{DAFTAR PUSTAKA}

Gaelzer, M.M. et al., 2017. Hypoxic and Reoxygenated Microenvironment: Stemness and Differentiation State in Glioblastoma. Mol Neurobiol, 54, pp.6261-6272.

Garcia-Mazas, C., Csaba, N. \& Garcia-Fuentes, M., 2017. Biomaterials to suppress cancer stem cells and disrupt their tumoral niche. International Journal of Pharmaceutics , 523, pp.490-505.

Greaves, M. \& Maley, C.C., 2012. Clonal evolution in cancer. Nature, 481, pp.306-13.

Jain, R., 2005. Normalization of tumor vasculature: an emerging concept in antiangiogenic therapy. Science, 80 (307), pp.58-62.

Liu, S. et al., 2011. Breast cancer stem cells are regulated by mesenchymal stem cells through cytokine networks. Cancer Res, 71, pp.614 24.

Magee, J.A., Piskounova, E. \& Morrison, S.J., 2012. Cancer Stem Cells: Impact, Heterogeneity, and Uncertainty. Cancer Cell, 21, pp.283-96.

Waterman, R., Henkle, S. \& Betancourt, A., 2012. Mesenchymal stem cell 1 (MSC1)-based therapy attenuates tumor growth whereas MSC2- treatment promotes tumor growth and metastasis. PloS One, 7, p.e45590.

Xie, T. \& Li, L., 2007. Stem cells and their niche: an inseparable relationship. Development, 134, pp.2001-2006.

Yua, Z., Pestellc, T.G., Lisantic, M.P. \& Pestell, R.G., 2012. Cancer stem cells. The International Journal of Biochemistry \& Cell Biology, 44, pp.2144-2151. 